\title{
MULTIDISCIPLINARY TREATMENT OF CONGENITALLY MISSING MAXILLARY LATERAL INCISORS: A CASE REPORT
}

\author{
TRATAMENTO MULTIDISCIPLINAR DE AGENESIAS DE INCISIVOS LATERAIS \\ SUPERIORS: RELATO DE CASO
}

\section{Analice Giovani PEREIRA ${ }^{\mathbf{1}}$; Paulo Vinícius SOARES ${ }^{\mathbf{2}}$; Lívia Fávaro ZEOLA ${ }^{\mathbf{1}}$; Alexandre Coelho MACHADO ${ }^{1}$; Daniela Navarro Ribeiro TEIXEIRA ${ }^{3}$; Cristianne Pacheco RIBEIRO ${ }^{4}$; Maria Aparecida de Oliveira CAMPOLI ${ }^{4}$; Luís Henrique Araújo RAPOSO ${ }^{5}$}

1. Postgraduate Student, Nucleus of Extension, Research and Teaching at NCCL, School of Dentistry, Federal University of Uberlândia, Brazil; 2. Professor at Operative Dentistry and Dental Materials Department and Coordinator of Nucleus of Extension, Research and Teaching at NCCL, School of Dentistry, Federal University of Uberlândia, Brazil; 3. Undergraduate Student, Nucleus of Extension, Research and Teaching at NCCL, School of Dentistry, Federal University of Uberlândia, Brazil; 4. Professor at Periodontics and Implantology Department, School of Dentistry, Federal University of Uberlândia; 5. Professor at Occlusion, Fixed Prosthodontics and Dental Materials Department, School of Dentistry, Federal University of Uberlândia. luisrfox@ gmail.com

\begin{abstract}
Congenital tooth agenesis and tooth loss due to dental traumatism are some of the most common causes leading to rehabilitation of young patients with dental implants. The success of treating congenitally missing teeth with implant-supported prosthesis is no more guided only by osseointegration criteria. Nowadays the successful rehabilitation of these cases involves the adequate installation of dental implants with suitable prosthetic contour, color, and emergence profile closer to that found in natural dentition. Several treatment options are available for restoring patients with congenitally missing teeth such as maxillary lateral incisors. Fixed prosthodontics and orthodontics managements are considered acceptable treatment protocols. However, the gold standard rehabilitation of congenitally missing maxillary incisors is performed with implant-based prosthesis since no tooth wear neither extensive tooth movements are necessary. The present paper reports the treatment of a young adult woman with congenitally missing maxillary lateral incisors who underwent orthodontic treatment for improvement of teeth alignment and occlusal balance previous to dental implant surgery. This treatment also allowed appropriate space for the future lateral incisors crowns. Then, Morse-type conical implants were positioned and prosthetic abutments installed. Ceramic laminates were planned on central incisors in order to improve anterior aesthetics. All-ceramic crowns and laminates were made using lithium dissilicate-based ceramic (e-Max Press). The multidisciplinary association of orthodontic, implant and prosthetic techniques resulted in successful functional and aesthetic rehabilitation of the case, which was maintained after 1 year follow up.
\end{abstract}

KEYWORDS: Ceramic laminates. Dental agenesis. Dental implants. Esthetic.

\section{INTRODUCTION}

Dental agenesis is the absence or failure on teeth formation. Absence of permanent maxillary lateral incisors represents approximately $20 \%$ of all cases of dental agenesis, and this anomaly is more common to occur unilaterally (GALLER, et al. 2009). Restorative dentists and orthodontists have many treatment plan options when restoring partially edentulous patients. However, the use of endosseous dental implants has become the treatment of choice for restoring patients with congenitally missing teeth. Dental implant therapy can restore such patients with acceptable esthetic and functional outcomes as well as enhanced clinical prognosis and patient satisfaction (ADELL, et al. 1981).

Missing maxillary lateral incisors create an esthetic problem with specific orthodontic and prosthetic considerations. Dental implants are commonly used to replace congenitally missing lateral incisors in young orthodontic patients (DE AVILA, et al. 2012). However, an interdisciplinary approach should be observed during the diagnosis, prognosis, and treatment plan to provide a result with good predictability, reaching the esthetic and functional expectations of the patient (ZARONE, F. et al.2006).

If a patient presents congenitally missing maxillary lateral incisor, the width of the space for the implant and crown is determined by opposite lateral incisor. However, in other situations, when both lateral incisors are congenitally absent, the amount of space for the implant and crown is determined by crowding, profile, crown shape and color, smiling lip level and occlusion (ZARONE, et al.2006, KOKICH, 2004).The orthodontic phase must achieve several clinical criteria before the initiation of the implant surgical stage (SPEAR, et al, 1997). The occlusion must ensure a stable 
posterior intercuspation with an ideal overjet and overbite. The anterior edentulous area needs to allow sufficient space between an implant and the adjacent tooth, thereby allowing for stable crestal bone levels and ideal dental papilla formation (ESPOSITO, et al.1993).

The decision to keep spaces from missing lateral incisors or to close them orthodontically should be evaluated carefully after consideration of both the treatment plan and the biomechanics (SABRI, 1999, BAIDAS; HASHIM 2005). In addition, the Golden Proportion parameters allows for the establishment of the ideal width proportion of the maxillary lateral incisor to its adjacent central incisor (LOMBARDI, 1973). Further, anterior maxillary aesthetics can be improved by minimally invasive aesthetic procedures such as ceramic laminates supplementing the outcomes of orthodontic and implant treatments.

Since missing lateral incisors are not rare in population and the multidisciplinary planning is fundamental on treatment success, the aim of the present paper was to report a case of maxillary lateral incisor bilateral agenesis in a young patient in which the multidisciplinary treatment allowed suitable resolution with excellent reestablishment of function and aesthetics.

\section{Case Report}

\section{Treatment Planning}

A 30-year-old woman presented bilateral congenitally missing maxillary lateral incisors. The patient's medical history had no significant findings. Orthodontic treatment was proposed for improving dental alignment and occlusal balance, and after its conclusion, two Morse-type conical implants were installed on the sites correspondent to right and left maxillary lateral incisors. Periapical radiograph was taken after selecting the prosthetic abutments in order to verify implants positioning and abutments adaptation (Figure 1A). Provisional crowns were made over the prosthetic abutments with adequate anatomic contour in order to promote suitable gingival conditioning (Figure 1B).
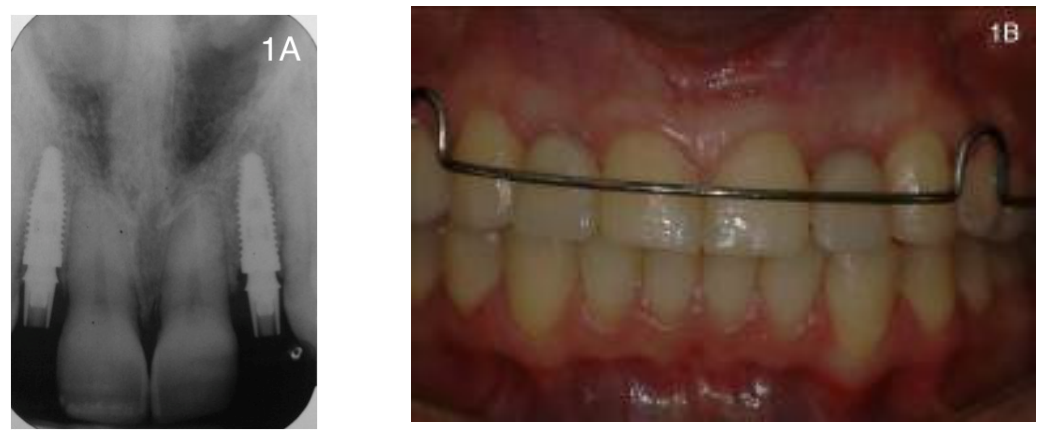

Figure 1. Patient smile view after orthodontic treatment and implant surgery. A - Radiographic aspect of the implants after abutment selection and installation. B - Buccal view of patient's provisional crowns in function.

The correct tridimensional positioning of the implants allowed sufficient amount of bone and gingival tissue, which are extremely important for maintenance of supporting tissues on buccal side. The suitable palatal implant approach is crucial on keeping harmonic gingival architecture (Figure 2).
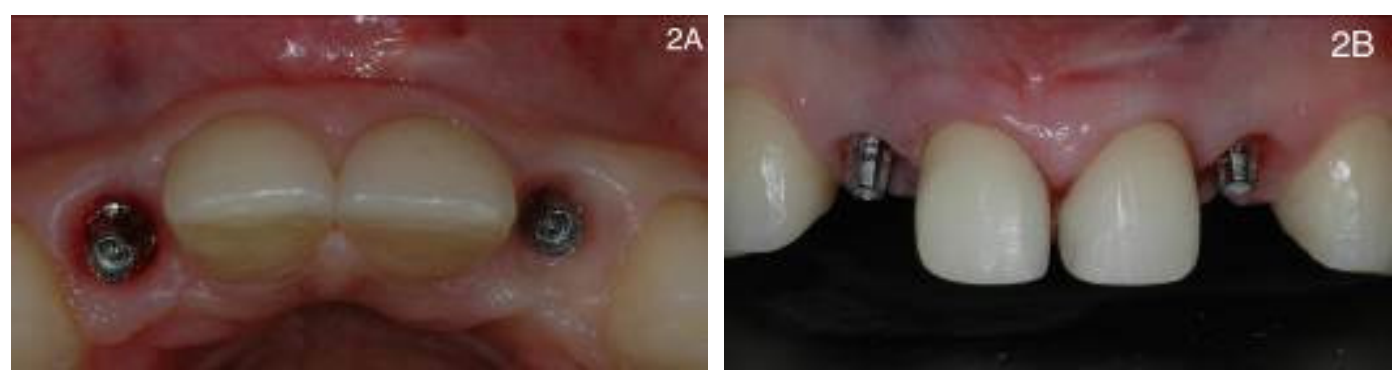

Figure 2. Gingival conditioning, buccal arch contour and soft healthy tissue aspect. A - Occlusal view. B Buccal view. 


\section{Dental preparation and impression}

Waxing analysis was used to plan minimally invasive ceramic laminates for the central incisors since their shape need improvements. Minimal wear was performed to ensure direction of insertion and resistance to the restorative materials (ceramic laminates). During preparation, all angles were rounded using extrafine tapered-cylinder round-end diamond burs (\#2135FF KG Sorensen, Brazil), silicone rubbers (Enhance, 3M ESPE, USA), abrasive disks (Pop-On, 3M ESPE), and felt disks (Feltros Diamond, FGM Products, Brazil) to smooth the prepared surfaces.

Impression of the prosthetic abutments and prepared teeth was performed using
PEREIRA, A. G. et al.

polyvinylsyloxane-based material (Virtual, IvoclarVivadent, Liechtenstein) and retraction cords (Ultrapack, Ultradent Products, USA) (Figure 3). The accuracy on coping gingival groove favors determining cervical finishing for the ceramic laminates, which must be perfectly adapted to tooth enamel. The ceramic laminates and the prosthetic crowns were made with lithium dissilicate-based ceramic (e-Max Press, Ivoclar-Vivadent, Liechtenstein). High fracture resistance and good aesthetic performance are some of the properties of lithium dissilicate ceramics (Park et al., 2010), what guided the material choice.

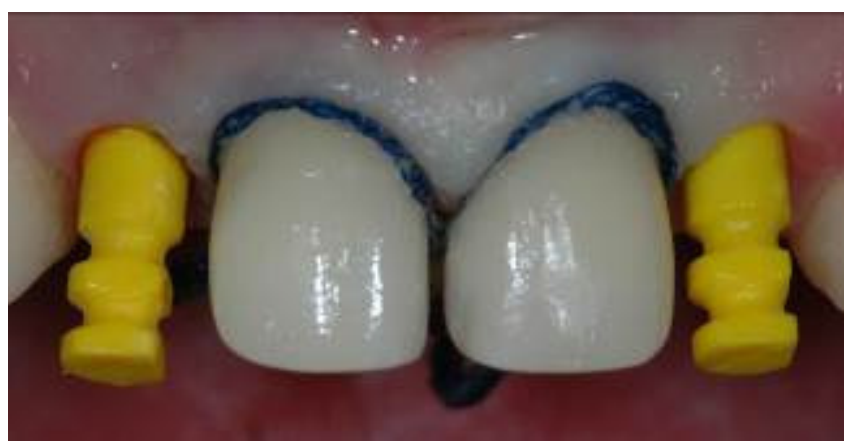

Figure 3. A - Impression step: retraction cord and impression abutments.

\section{Restoration checking and cementation}

Mock-up restorations were built using bisacryl resin (Luxatemp Plus, DMG, Hamburg, Germany), in order to allow patient to try color, shape and function of the restorations before the final rehabilitation. All functional and esthetic adjustments should be ideally performed on the mock-up restoration previous to laminate confection, since thin restorations are delicate pieces that cannot be worn. Checking of both full crown and ceramic laminates was carefully performed since direction of insertion of the restorations and fit must be verified before luting. Ceramic laminates can also be influenced by the luting agent color due its reduced thickness, so testing the luting agent shade before final luting also becomes an important step.

The internal surfaces of the crowns and laminates were etched with $9.5 \%$ hydrofluoric acid for 20 seconds (Condicionador de Porcelanas, Dentsply, Brasil). The surfaces were washed with water and 37\% phosphoric acid was applied for 60 seconds (Total Etch, Ivoclar Vivadent) followed by cleaning. The ceramic restorations were silanized with a silane coupling agent (Monobond Plus, Ivoclar Vivadent) actively applied for 1 minute. Etching of enamel was performed with $37 \%$ phosphoric acid for 30 seconds (Total Etch, IvoclarVivadent) followed by application of a total-etch single component adhesive system (ExciTE F DSC, Ivoclar-Vivadent). Light-curing resin cement (Variolink Veneer, Ivoclar-Vivadent) was used to lute the ceramic laminates. Excess cement was removed with a disposable brush applicator (KG Brush, KG Sorensen), and each surface was photoactivated for 60 seconds by a LED-curing unit with $1200 \mathrm{~mW} / \mathrm{cm}^{2}$ light output (Radii Plus, SDI, Australia). The full all-ceramic crowns were luted using self-etching dual cure resin cement (Rely-X Unicem, 3M-ESPE, Germany) according to the manufacturer's instructions. Occlusal contacts were marked, and protrusive and lateral movements were checked.

The appropriate planning and multidisciplinary execution of the restorative steps allowed successful rehabilitation of the case (Figure 4). 

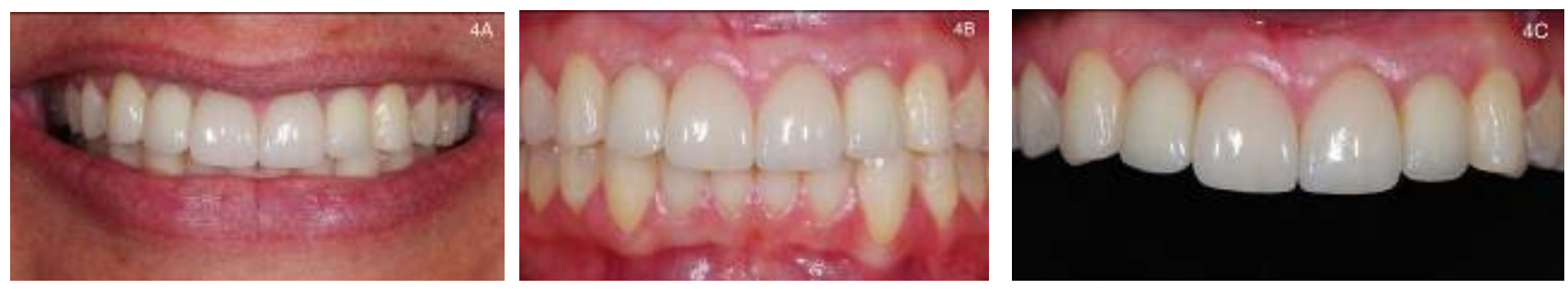

Figure 4. A - Pacient's smile after one year clinical follow-up. B - Buccal arch contour and occlusion. C Buccal view of anterior teeth.

\section{DISCUSSION}

The absence of maxillary lateral incisors is the most frequent type of congenitally missing teeth among different populations (ALTUG-ATAC; ERDEM, 2007). Dental agenesis in the maxillary anterior region compromises smile balance and symmetry (ARAUJO, et al. 2006) and therefore, the treatment of these patients requires an interdisciplinary approach aiming to rehabilitate the smile, both in terms of function and aesthetics (ROSA; ZACHRISSON 2007).

Many treatment options are available to congenitally missing teeth. The advantages of orthodontically distalizing permanent canines into proper position, followed by implant placement in the regions corresponded to maxillary lateral incisors has been demonstrated in current literature (SPEAR, et al, 1997). The major benefit is the development of a stable residual alveolar ridge in the incisor region as the canine is orthodontically distalized. Since the canines play important role on occlusal movements due to anatomic and osseous aspects, the decision of moving them to the lateral incisors position is not the most proper treatment option. Some studies compared the patient's opinion about different treatment approaches for restoring missing lateral incisors. When comparing the orthodontic treatment to open space associated to single-unit implant and implant-based prosthesis to orthodontic treatment to open space associated to conventional fixed bridge or other prosthetic solutions, patients declared more problems when rehabilitated using the second option (DUELED, et al, 2009).

The same declarations were found on the comparison of reshaping the canine to placement of an adhesive fixed bridge, when remodeling the canine produced greater satisfaction than did filling the space with an adhesive fixed prosthesis (ROBERTSSON; MOHLIN 2000). Teeth replacement with implant-supported crowns is the best treatment choice because it allows preservation of adjacent teeth, resulting in great satisfaction of patients. Thus, this treatment option can be considered a safe and predictable rehabilitation protocol. Aesthetic aspects must also be carefully watched since anterior maxillary teeth play important role on smile esthetic by patients and professionals (DE-MARCHI. et al, 2012). The correct tridimensional positioning of implants enables suitable prosthetic contour and natural gingival fit.

The detailed analysis of the adjacent teeth and smile line is useful for achieving adequate rehabilitation planning. In the present case report, the waxing guided the indication of ceramic laminates on central incisors since their anatomic form could be improved with a better shape. Ceramic laminates are minimally invasive restorative procedures which require minimum wear of tooth structure, therefore, representing suitable option for aesthetic treatments. Lithium disilicatebased ceramic was used due its biomechanical properties and good aesthetics (PARK et al, 2010). These restorations can be influenced by the color of the luting agent, so the try-in procedure with different shades before permanent cementation is decisive on the final aesthetic result. On the present case, try-in pastes (Ivoclar-Vivadent) were used on laminates before final luting.

\section{CONCLUSION}

The appropriate multidisciplinary rehabilitation of congenitally missing lateral incisors with previous orthodontic treatment, followed by correct tridimensional implant positioning and well fit lateral incisor implant-supported crowns associated to ceramic laminates on central incisors was effective in successfully restoring function and aesthetics for the case reported.

\section{ACKNOWLEDGMENTS}

The authors are indebted to Mr. Marco Aurélio Dias Galbiatti, dental ceramist at Uberlândia-MG, Brazil. 
RESUMO: Agenesias e perdas dentárias devido a traumatismos estão entre as principais causas de reabilitações de pacientes jovens com implantes dentários. O sucesso do tratamento de agenesias com implantes osseointegrados não se limita mais à osseointegração exclusivamente. Atualmente, o sucesso da reabilitação destes casos envolve a correta instalação de implantes que favoreçam a confecção de uma prótese com cor, forma e perfil de emergência o mais semelhante possível aos dentes naturais. Os cirurgiões-dentistas têm várias opções para tratar casos de agenesias como as de incisivos laterais superiores. Próteses fixas convencionais e movimentação ortodôntica são considerados protocolos de tratamento aceitáveis. Entretanto, agenesias de incisivos laterais superiores são reabilitadas satisfatoriamente com próteses sobre implantes uma vez que extensas movimentações ou desgastes dentários são necessários. O presente caso relata o tratamento de uma paciente jovem com agenesia dos incisivos laterais que havia feito tratamento ortodôntico para correção do posicionamento dentário e equilíbrio dental antes de se submeter à cirurgia para instalação de implantes. O tratamento ortodôntico também favoreceu a obtenção de espaço apropriado para instalação das coroas dos incisivos laterais. Posteriormente, implantes cônicos com plataforma protética tipo cone morse foram instalados e pilares selecionados. Laminados cerâmicos foram planejados para os incisivos centrais com objetivo de se promover um resultado final mais harmônico e estético. As coroas em cerâmica pura e laminados foram confeccionados com cerâmica a base de dissilicato de lítio (e.Max Press). A associação multidisciplinar entre tratamento ortodôntico, implantes e próteses sobre implantes resultou no sucesso funcional e estético da reabilitação do presente caso com acompanhamento clínico de uma ano.

PALAVRAS-CHAVE: Agenesia. Laminados cerâmicos. Implantes dentários. Estética.

\section{REFERENCES}

ADELL, R., LEKHOLM, M., ROCKLER, B., BRANEMARK, P. I. A 15-year study of osseointegrated implants in the treatment of the edentulous jaw. Int J Oral Surg, Copenhagen, v. 10, n. 6, p. 387-416, 1981. http://dx.doi.org/10.1016/S0300-9785(81)80077-4

ALTUG-ATAC, A. T.; ERDEM, D. Prevalence and distribution of dental anomalies in orthodontic patients. Am J Orthod Dentofacial Orthop, St. Louis, v. 131, n. 4, p. 510-4, 2007.

ARAUJO, E. A., OLIVEIRA, D. D., ARAUJO, M. T. Diagnostic protocol in cases of congenitally missing maxillary lateral incisors. World J Orthod, Carol Stream, v. 7, n. 4, p. 376-88, 2006.

BAIDAS, L.; HASHIM, H. An anterior tooth size comparison in unilateral and bilateral congenitally absent maxillary lateral incisors. J Contemp Dent Pract, New Delhi, v. 6, n. 1, p. 56-63, Feb 152005.

DE AVILA, E. D., DE MOLON, R. S., DE ASSIS, M. F. JR., DE BARROS, L. A., CAPELOZZA FILHO, L., DE ALMEIDA, C. M., CIRELLI, J. A. Multidisciplinary approach for the aesthetic treatment of maxillary lateral incisors agenesis: thinking about implants? Oral Surg Oral Med Oral Pathol Oral Radiol, New York, v. 114, n. 5, p. e22-8, 2012. http://dx.doi.org/10.1016/j.oooo.2011.09.023

DE-MARCHI, L. M., PINI, N. I., PASCOTTO, R. C. The relationship between smile attractiveness and esthetic parameters of patients with lateral agenesis treated with tooth recontouring or implants. Clin Cosmet Investig Dent, Auckland, v. 4, p. 43-9, 2012. http://dx.doi.org/10.2147/CCIDEN.S37668

DUELED, E., GOTFREDSEN, K., TRAB DAMSGAARD, M., HEDE, B. Professional and patient-based evaluation of oral rehabilitation in patients with tooth agenesis. Clin Oral Implants Res, Copenhagen , v. 20, n. 7, p. 729-36, 2009. http://dx.doi.org/10.1111/j.1600-0501.2008.01698.x

ESPOSITO, M., EKESTUBBE, A., GRONDAHL, K.. Radiological evaluation of marginal bone loss at tooth surfaces facing single Branemark implants. Clin Oral Implants Res, Copenhagen, v. 4, n. 3, p. 151-7, 1993. http://dx.doi.org/10.1034/j.1600-0501.1993.040306.x

GALLER, D., QUIONG, G., GALLER, J,. A multi-disciplinary approach to congenitally missing anterior teeth. N Y State Dent J, New York, v. 75, n. 1, p. 51-3, 2009. 
KOKICH, V. G. Maxillary lateral incisor implants: planning with the aid of orthodontics. J Oral Maxillofac Surg, Philadelphia, v. 62, n. 9 Suppl 2, p. 48-56, 2004. http://dx.doi.org/10.1016/j.joms.2004.05.210

LOMBARDI, R. E. The principles of visual perception and their clinical application to denture esthetics. $\mathbf{J}$ Prosthet Dent, St. Louis, v. 29, n. 4, p. 358-82, 1973.

PARK, D. J., YANG, J. H., LEE, J. B., KIM, S. H., HAN, J. S.. Esthetic improvement in the patient with one missing maxillary central incisor restored with porcelain laminate veneers. J Adv Prosthodont, Seoul, v. 2, n. 3, p. 77-80, 2010. http://dx.doi.org/10.4047/jap.2010.2.3.77

ROBERTSSON, S.; MOHLIN, B. The congenitally missing upper lateral incisor. A retrospective study of orthodontic space closure versus restorative treatment. Eur J Orthod, Oxford, v. 22, n. 6, p. 697-710, 2000. http://dx.doi.org/10.1093/ejo/22.6.697

ROSA, M.; ZACHRISSON, B. U. Integrating space closure and esthetic dentistry in patients with missing maxillary lateral incisors. J Clin Orthod, Boulder, v. 41, n. 9, p. 563-73, 2007.

SABRI, R. Management of missing maxillary lateral incisors. J Am Dent Assoc, Chicago, v. 130, n. 1, p. 804, 1999. http://dx.doi.org/10.14219/jada.archive.1999.0032

SPEAR, F. M., MATHEWS, D. M., KOKICH, V. G. Interdisciplinary management of single-tooth implants. Semin Orthod, Philadelphia, v. 3, n. 1, p. 45-72, 1997. http://dx.doi.org/10.1016/S1073-8746(97)80039-4

ZARONE, F. SORRENTINO, R., VACCARO, F., RUSSO, S. Prosthetic treatment of maxillary lateral incisor agenesis with osseointegrated implants: a 24-39-month prospective clinical study. Clin Oral Implants Res, Copenhagen, v. 17, n. 1, p. 94-101, 2006. http://dx.doi.org/10.1111/j.1600-0501.2005.01188.x 